\title{
Metal-organic framework MIL-100(Fe) as a novel moisture buffer material for energy- efficient indoor humidity control
}

\author{
Feng, Xiaoxiao; Qin, Menghao; Cui, Shuqing; Rode, Carsten
}

\section{Published in:}

Building and Environment

Link to article, DOI:

10.1016/j.buildenv.2018.09.027

Publication date:

2018

Document Version

Peer reviewed version

Link back to DTU Orbit

Citation (APA):

Feng, X., Qin, M., Cui, S., \& Rode, C. (2018). Metal-organic framework MIL-100(Fe) as a novel moisture buffer material for energy-efficient indoor humidity control. Building and Environment, 145, 234-242.

https://doi.org/10.1016/j.buildenv.2018.09.027

\section{General rights}

Copyright and moral rights for the publications made accessible in the public portal are retained by the authors and/or other copyright owners and it is a condition of accessing publications that users recognise and abide by the legal requirements associated with these rights.

- Users may download and print one copy of any publication from the public portal for the purpose of private study or research.

- You may not further distribute the material or use it for any profit-making activity or commercial gain

- You may freely distribute the URL identifying the publication in the public portal 


\title{
Metal-Organic Framework MIL-100(Fe) as a Novel Moisture Buffer Material for Energy-Efficient Indoor Humidity Control
}

\author{
Xiaoxiao Feng, Menghao Qin*, Shuqing Cui, Carsten Rode \\ Department of Civil Engineering, Technical University of Denmark, Lyngby 2800, Denmark \\ * Corresponding author: Dr. Menghao Qin, Tel.: +45 45254015 \\ E-mail address: menqin@byg.dtu.dk
}

Abstract: Metal-organic frameworks (MOFs) are a new class of porous materials composed of a three-dimensional network of metal ions held in place by multidentate organic molecules. MIL100(Fe) (molecular formula: $\left.\mathrm{Fe}_{3} \mathrm{O}\left(\mathrm{H}_{2} \mathrm{O}\right)_{2} \mathrm{OH}(\mathrm{BTC})_{2}\right)$, as one kind of MOFs, has an excellent performance of water sorption due to the large specific surface areas and high porosity. The paper proposes an innovative application of MIL-100(Fe) as a new kind of moisture buffer material to control the indoor humidity passively. MOFs can moderate indoor moisture fluctuation, which will greatly reduce the energy consumption of HVAC systems and improve the building energy efficiency. In the paper, microstructure and moisture characterizations of MIL-100(Fe) have been carried out. The moisture buffer value (MBV) of MIL-100(Fe) has been measured and compared to the typical building materials. The results show that MIL-100(Fe) can absorb up to $15 \mathrm{~g} \cdot \mathrm{m}^{-}$ ${ }^{2} \cdot \mathrm{RH}^{-1}$ at 8 hours, which is 33 times higher than the laminated wood. A novel lumped model for building latent load simulation has been developed. The energy saving potential by using MOFs in a typical office in different climates was calculated. The results show that a $5 \mathrm{~m}^{2} \mathrm{MOF}$ wall panel can remove most of the latent load in dry and moderate climates without any energy input; MOFs can be regenerated by night ventilation. In the hot and humid climate, the MOF materials can remove $73.4 \%$ of the latent load, and can be easily regenerated by using low-grade energy.

Keywords: Metal-organic framework; Moisture buffer value; Indoor humidity control; Energy saving 


\section{Introduction}

Buildings account for about $40 \%$ of the world's total energy consumption [1, 2], and more than $50 \%$ of the primary energy consumed in buildings is for the heating and air-conditioning system [3]. To ensure adequate supplies of energy and to curtail the growth of $\mathrm{CO}_{2}$ emissions, it is essential to improve the building energy efficiency and reduce the energy consumption of HVAC systems. One way to achieve this goal is through the introduction of innovative passive building materials that can regulate the indoor humidity, and maintain the indoor environment at a stable and comfortable level.

The loads of HVAC systems consist of sensible load and latent load. In some hot and humid climates, the latent load takes a significant proportion of the total cooling load [4], leading to considerable energy consumption in air dehumidification [5]. Hygroscopic materials and components in buildings, such as porous building materials and furniture, can adsorb/release moisture from/to the indoor air, and have a positive effect on moderating the indoor relative humidity (RH) fluctuations. Since the moisture buffer phenomenon occurs without energy use, the moisture buffer materials can reduce the energy use for humidification or dehumidification in buildings [6].

Previous studies on the moisture buffer materials for indoor humidity control mainly focus on the traditional and conventional building materials, such as concrete, drywall, brick, plywood, gypsum and combination of them [7,8]. In 2005, Rode et al. proposed the concept of the moisture buffer value (MBV) to evaluate the moisture buffer performance of different materials [7]. The MBVs of many traditional and conventional building materials have been measured according to the NORDTEST method [6, 7]. The test results show that the MBV of most traditional and conventional building materials is relatively low and imply a limited ability to moderate the indoor moisture variation [9-16]. The MBVs of some traditional building materials and 
conventional materials are listed in table 1 . The test temperature is $23^{\circ} \mathrm{C}$ and $\mathrm{RH}$ is $33 \% / 75 \%$. As a result, the energy saving potential by using the traditional or conventional hygroscopic building materials for moisture buffering is limited. Further studies on new materials are needed.

6

Table 1. MBV of some traditional/conventional materials [7, 10, 14-16] $\left(23^{\circ} \mathrm{C}, 33 \% / 75 \%\right)$

\begin{tabular}{lc}
\hline \multicolumn{1}{c}{ Material } & $\mathrm{MBV}\left(\mathrm{g} \cdot \mathrm{m}^{-2} \cdot \mathrm{RH}^{-1}\right)$ \\
\hline Gypsum & 0.26 \\
Diatomite & 0.33 \\
Concrete & 0.38 \\
Brick & 0.4 \\
Laminated Wood & 0.45 \\
Sepiolite & 0.54 \\
Vesuvianite & 0.79 \\
Spruce boards & 1.15 \\
\hline
\end{tabular}

Conventional desiccants, such as silicates, aluminophosphates, zeolites and activated charcoal, have high hydrophilicity, and show large water sorption capacity, and are widely used in many industrial and civil applications [17-20]. However, the regeneration temperature of most traditional desiccants is very high (normally higher than $100{ }^{\circ} \mathrm{C}$ ), which means these desiccants cannot release moisture in indoor conditions. Thus, these desiccants are not suitable for passive moisture regulation in buildings.

The ideal moisture buffer materials should have both high water uptake capacity and low regeneration temperature (i.e. the material could release moisture in room temperature when the indoor humidity is low.). Metal-organic frameworks (MOFs), a novel class of porous crystalline materials, have drawn large attention recently. Some MOFs possess the largest surface area, pore volume and lowest framework density among the existing porous solids and have high water 
96

uptake capacity [21-23]. Compared to some microporous materials, such as the desiccants mentioned above, the structure of MOFs has the potential for more flexible rational design [24], and the pore size of MOFs is tunable, leading to some unusual patterns of water sorption isotherm [21, 25]. Some MOFs can be regenerated under room temperature and humidity owing to their unique water sorption isotherms. However, in previous studies, applications on MOFs mainly focus on catalysis, gas sorption and storage, adsorption heat pump, sensor, and drug delivery [23, 26]. The application of MOFs in buildings as a moisture buffer material for energy-saving has not been reported yet.

In addition to the large adsorption ability, the MOFs for built environment application must possess other advantages such as water stable, a lack of toxicity, low regeneration temperature, low-cost and the possibility of scalable production. Many types of MOFs have been synthesized in the past several years, but few of them meet the above criteria [27-29]. We have investigated the performance of a few archetypal amphiphilic MOFs, including MIL-100(Fe), Basolite A520 (Aluminium Fumarate), MIL-125(Ti), UiO-66(Zr), and MOF-808(Zr) etc [30-33]. With one of the highest water uptake capacity ever reported, MIL-100(Fe) has a better overall performance than any other. We therefore chose MIL-100(Fe) for use in this paper.

This paper aims to apply MIL-100(Fe) as a novel moisture buffer material for the passive control of indoor humidity in different climates. First, the microstructure and moisture characterizations of MOF MIL-100(Fe) will be studied, and the moisture buffer value of the material in various conditions will also be measured. Secondly, a mathematical model will be set up to study the energy performance of MOF MIL-100(Fe) in a typical office room. Finally, the energy saving potential by using MOF materials in different climates will be discussed. 


\section{Characterization}

The sample of MIL-100(Fe) analyzed in this paper is synthesized by the École Normale Supérieure in Paris, France (the main partner of this research). The microstructure and moisture characterizations of MIL-100(Fe) have been measured and discussed in this section.

\subsection{Morphology}

Scanning electronic microscope (SEM) has been used to analyze the geometry of MIL-100(Fe) crystal. The sample of MIL-100(Fe) is not purified further after acquiring from the French partner. The images were taken by an FEI Quanta 200 ESEM FEG microscope equipped with an energy-dispersive X-ray (EDS) spectrometer. The SEM image is shown in Fig. 1. The tiny crystal of MIL-100(Fe) is octahedral with the size of $0.5-2 \mu \mathrm{m}$.

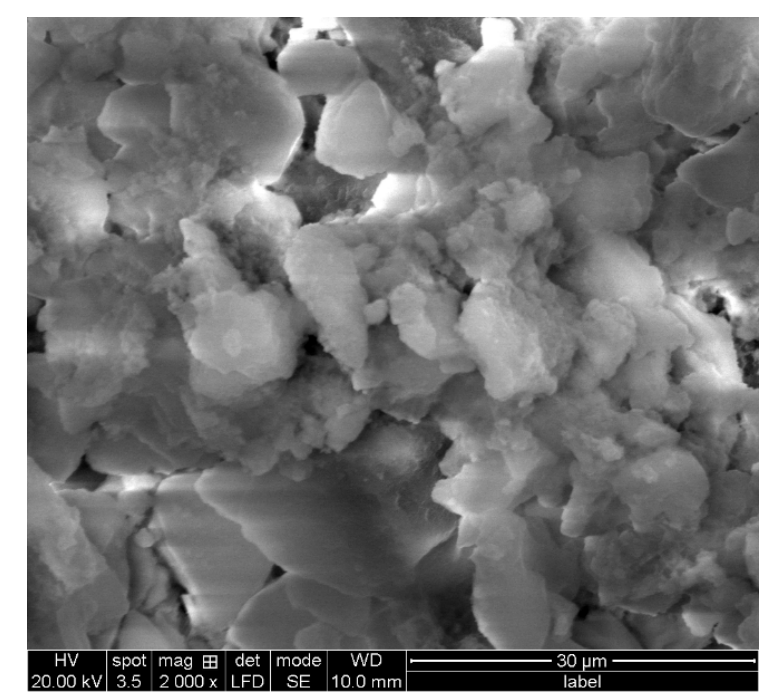

Figure 1. SEM images of MIL-100(Fe)

\subsection{Water sorption isotherms}

Water sorption isotherms illustrate a clear image of water sorption performance under different relative humidity. The isotherms were measured by a DVS (Dynamic vapor sorption) instrument (Surface Measurement Systems DVS Adventure). The sample of MIL-100(Fe) was first dried in 
DVS by the airflow with the temperature of $23^{\circ} \mathrm{C}$ and $\mathrm{RH}$ of $0 \%$ until weight did not change.

Then the RH of the airflow could be set, such as $0 \%, 10 \%, 20 \%$, etc. DVS will automatically record the weight of the sample when the weight of the sample retains constant at each RH point. The test result is shown in Fig. 2. The temperature during the measurements remains at $23^{\circ} \mathrm{C}$. The steep adsorption occurs at $\mathrm{RH}=25 \%$ and $\mathrm{RH}=40 \%$, respectively. This is mainly because that MIL-100(Fe) has a polymodal pore size distribution, from both $25 \AA$ and $29 \AA$ mesopores. Saturation approaches when the relative humidity reaches $50 \%$. When the relative humdity is higher than 50\%, the mass increase is slight. Adsorption occurs in the inter-particulate voids. For the desorption curve, a visible hysteresis occurs, especially for the $29 \AA$ meso-pores. The test result has a good agreement with the previous studies [23, 25]. moisture buffer performance.

However, the water sorption isotherms of MIL-100(Fe) shows a promising result for the passive 140 indoor moisture control. Since the steep adsorption begins at $\mathrm{RH}=25 \%$ and ends at $\mathrm{RH}=50 \%$ at $23^{\circ} \mathrm{C}$, MIL-100(Fe) can adsorb the moisture when the indoor relative humidity is higher than $50 \%$, and release the moisture when the relative humidity is lower than $25 \%$. Therefore, MIL- 

[37] zone passively.

145
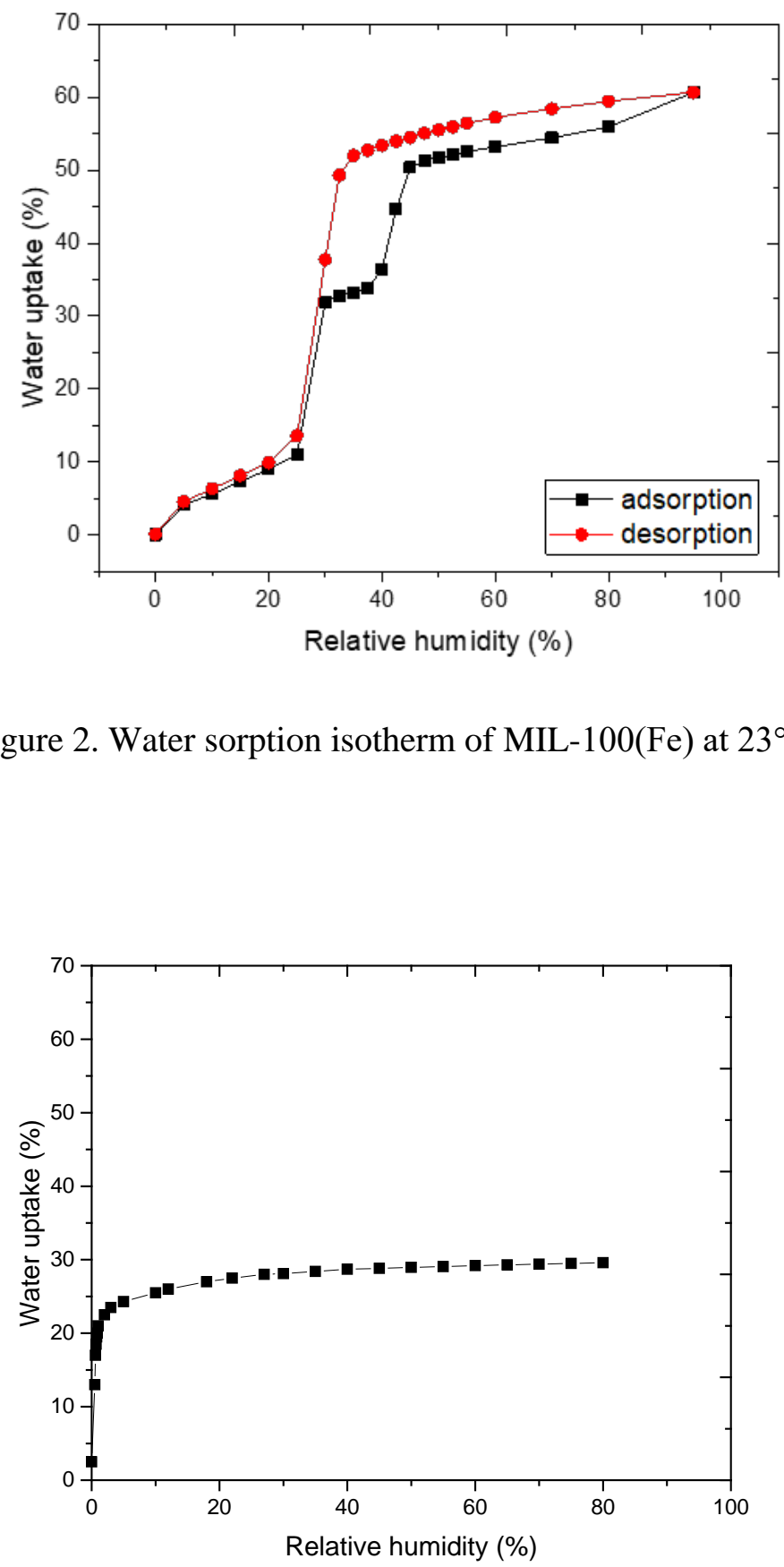

149

Figure 3. Water vapor adsorption isotherm of zeolite $13 \mathrm{X}$ (Sigma-Aldrich) at $25{ }^{\circ} \mathrm{C}$ [34] 


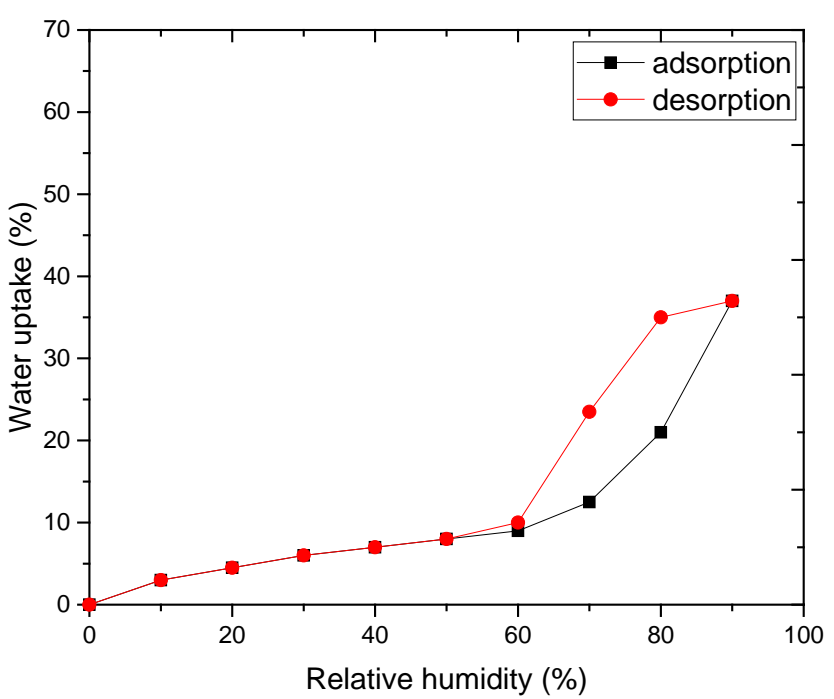

151

\section{Moisture Buffer Value}

3.1 Definition of moisture buffer value (MBV)

The moisture buffer performance of a room is the ability of the materials within the room to moderate variations in the relative humidity. These variations can be seasonal or diurnal. Most attention is paid to the moisture buffering of diurnal variations. The moisture buffer performance depends on the moisture buffer capacities of each material combination and furniture in the room together with the moisture production and air change rate and ratio between the material surface area and the air volume.

To evaluate the moisture buffer effect of materials, moisture buffer value (MBV) has been proposed $[6,7]$. MBV is defined as a characteristic of material, equals to the moisture uptake per relative humidity change during one cycle of moisture adsorption or release. An ideal MBV can be derived by assuming that the material is isotropic and semi-infinite, the boundary conditions

167 are the alternating high and low relative humidity of the surface, neglecting the surface moisture convection. 
170 The expression of ideal MBV is as follows.

$$
M B V=\frac{G(t)}{\Delta R H}=0.00568 b_{\mathrm{m}} p_{\mathrm{s}} \sqrt{t_{\mathrm{p}}}
$$

171 Where, $b_{\mathrm{m}}$ is the moisture effusivity, $\mathrm{kg} \cdot \mathrm{m}^{-2} \cdot \mathrm{Pa}^{-1} \cdot \mathrm{s}^{-1 / 2} ; p_{\mathrm{s}}$ is the saturated vapor pressure, $\mathrm{Pa} ; t_{\mathrm{p}}$ is

172 the time period, s.

173 The $b_{\mathrm{m}}$ can be expressed as follows.

$b_{m}=\sqrt{\frac{\delta_{p} \cdot \rho_{0} \cdot \frac{\partial u}{\partial \varphi}}{p_{s}}}$

175 Where $\delta_{p}$ is the water vapor permeability, $\mathrm{kg} \cdot \mathrm{m}^{-1} \cdot \mathrm{s}^{-1} \cdot \mathrm{Pa}^{-1} ; \rho_{0}$ is the dry density of the material,

$176 \mathrm{~kg} \cdot \mathrm{m}^{-3} ; u$ is the moisture content, $\mathrm{kg} \cdot \mathrm{kg}^{-1} ; \varphi$ is the relative humidity, \%.

177

Meanwhile, MBV can be measured directly by experiment without acquiring the thermal properties of the material. The MBV tested by experiments named practical MBV. In a certain period of time, the ambient humidity alternates between high level and low level. The moisture transports into or out of the material during the period of time is reported per open surface area and per \% RH variation, and it is the definition of practical MBV, with a unit of $\mathrm{g} \cdot \mathrm{m}^{-2} \cdot \mathrm{RH}^{-1}$.

Therefore, the definition of practical MBV is the principle of MBV measurement.

\subsection{MBV measurement}

\subsubsection{Method}

Based on the definition of the practical MBV, the MBV of MIL-100(Fe) has been measured. First, the sample of MIL-100(Fe) $(\mathrm{L} \times \mathrm{W} \times \mathrm{H}=2.8 \times 2.5 \times 3 \mathrm{~cm})$ was dried in an oven for 10 hours at $60^{\circ} \mathrm{C}$. Then the sample was sealed in a glass container in the climate chamber until the temperature of the samples dropped to the chamber temperature, which was $23^{\circ} \mathrm{C}$. 

chamber is $23^{\circ} \mathrm{C}$. The external ambient temperature is between $20 \sim 25^{\circ} \mathrm{C}$. The temperature and humidity sensors measure the temporal temperature and relative humidity, and the signal is sent back to a PID regulator and computer. Saturated air and dry air can be mixed in different proportion controlled by the PID regulator to maintain a stable humidity in the chamber. A heater

197 is placed in the chamber and also controlled by the regulator to keep a stable temperature. An 198 axial fan disturbs the air in the chamber to approach a uniform hydrothermal condition in the 199 chamber. Fig. 5 shows the schematic diagram of the climate chamber.

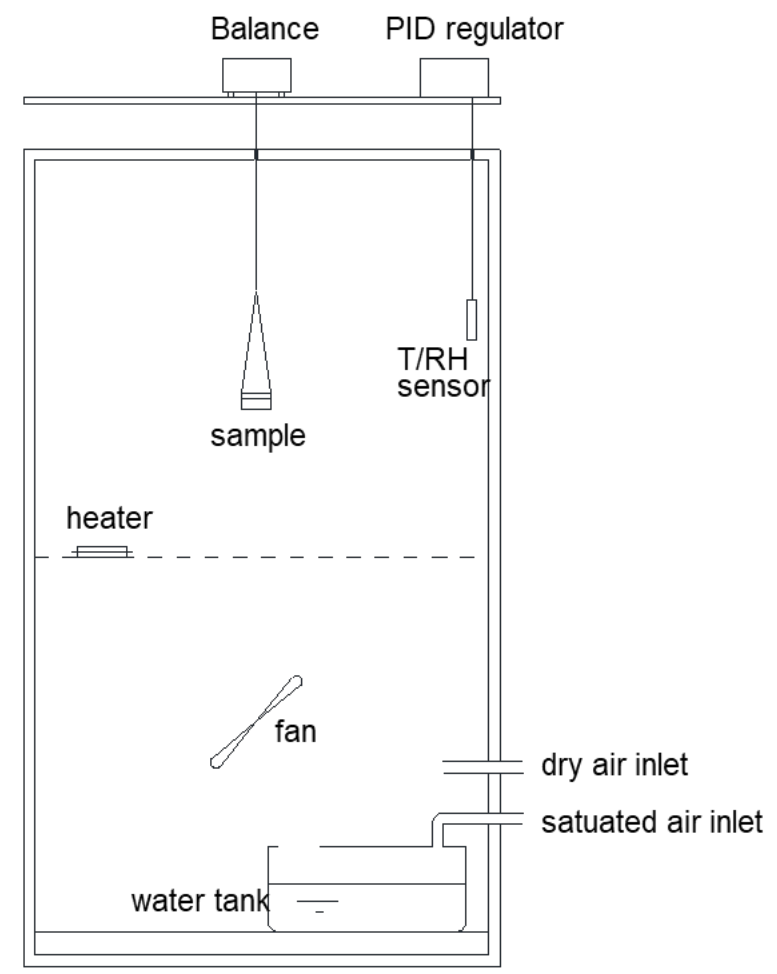




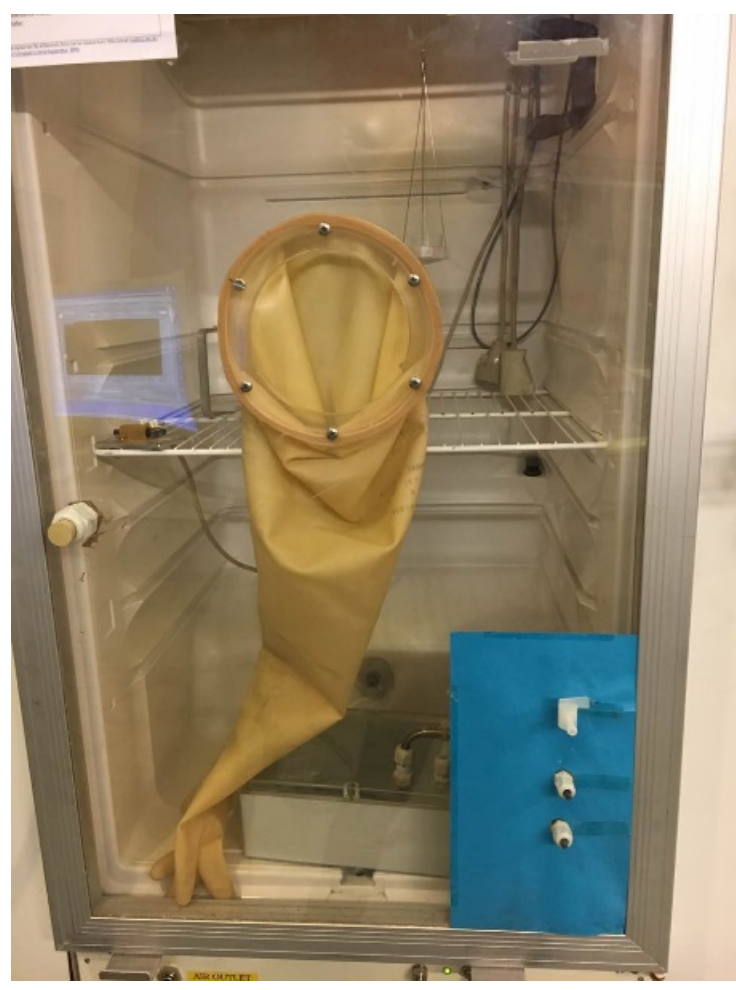

Figure 6. Photo of the climate chamber

206

The MIL-100(Fe) sample was placed in a small box and was suspended in the climate chamber connected with a balance above the chamber (Fig. 5). Only the upper surface of the sample (7 $\mathrm{cm}^{2}$ ) was exposed to the air inside the climatic chamber. The rest five surfaces were sealed to avoid moisture transport. The test conditions in the climate chamber were set according to the NORDTEST method [7]. The temperature and humidity inside the climate chamber are uniform as a small axial fan is installed to make the inside air well mixed. The temperature inside the chamber was maintained at $23{ }^{\circ} \mathrm{C}$, and the relative humidity was set as $75 \%$ for 8 hours and $20 \%$ for 16 hours in one period of time. The air humidity was switched swiftly. The weight of MIL100(Fe) sample was weighed and logged automatically with the balance every minute. The measurement was performed in several cycles to get a relatively constant MBV of the material.

217 Fig. 6 is the photo of the climate chamber when the measurement is performing. 
221 The measurement results are shown in Fig. 7. The mass change of the sample corresponds rapidly with the surrounding humidity change. The sharp peak of the curve shows that the sample

223 is far from saturation when the humidity begins to fall. The MBV of the MIL-100(Fe) is $15 \pm 0.2$ $\mathrm{g} \cdot \mathrm{m}^{-2} \cdot \mathrm{RH}^{-1}$ at 8 hours in the experimental conditions. Fig. 8 shows the MBV test results with a different low humidity level 33\%. Other conditions maintain the same. The MBV of MIL-

$226100(\mathrm{Fe})$ is $7.4 \pm 0.2 \mathrm{~g} \cdot \mathrm{m}^{-2} \cdot \mathrm{RH}^{-1}$ at 8 hours, which is lower than the result in the $75 \%$ / $20 \%$ 227 condition.

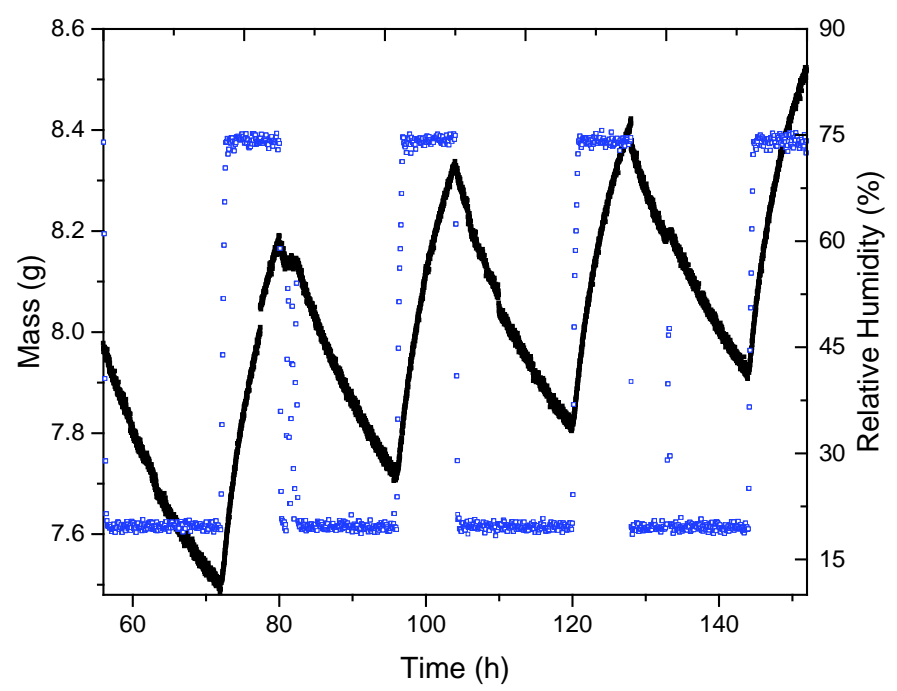

Figure 7 . MBV test at $23^{\circ} \mathrm{C}(\mathrm{RH}=20 \% / 75 \%)$

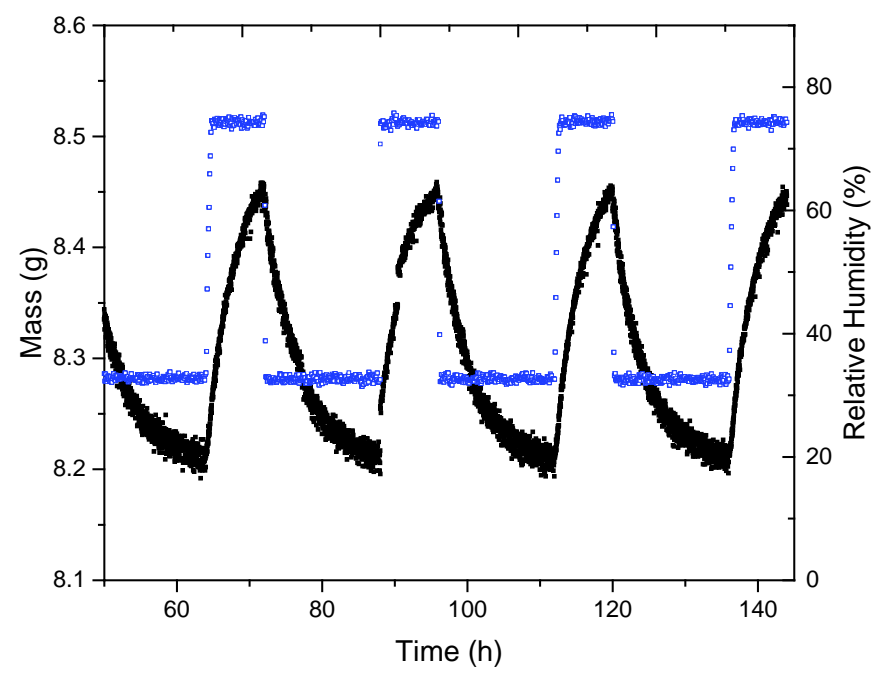

Figure 8 . MBV test at $23^{\circ} \mathrm{C}(\mathrm{RH}=33 \% / 75 \%)$ 


\subsubsection{Discussion}

235 According to the expression of the moisture effusivity $b_{m}$ (Eq. 2), $b_{m}$ has a significant relation to

236 the sorption isotherm. The term $\frac{\partial u}{\partial \varphi}$ represents the moisture capacity, i.e. the ratio of the moisture 237 added to a material to the resulting humidity change. It is not a constant and varies according to 238 the water sorption isotherm. Therefore, the MBV value (shown in Eq. 1) is also not a constant, 239 and will change according to different upper and lower boundary of RH. In the case of MIL$240100(\mathrm{Fe})$, If the low-level relative humidity is above the first steep adsorption point $(\mathrm{RH}=25 \%)$, 241 which is also the end of desorption, the moisture buffer performance of the material will be hindered. Therefore, the MBV in an alternative 75\% / 33\% condition is lower than that of 75\% / $20 \%$.

The MBVs of some typical building materials are listed in Table 1. In line with different levels of MBV, Materials can be classified into six categories, shown in Table 2. Therefore, MBV of the MIL-100(Fe) is one order of magnitude larger than the traditional hygroscopic building materials, and the moisture buffering ability of MIL-100(Fe) is in the exceptional group.

Table 2. Classification of MBV

\begin{tabular}{ccccccc}
\hline MBV & negligible & limited & moderate & good & excellent & exceptional \\
\hline Lower limit & 0 & 0.25 & 0.50 & 1.00 & 2.00 & 5.00 \\
Upper limit & 0.25 & 0.50 & 1.00 & 2.00 & 5.00 & $>5.00$ \\
\hline
\end{tabular}

251

Furthermore, the moisture adsorption in different conditions can be calculated based on the water sorption isotherm and MBV formula. Fig. 9 shows the water vapor uptake of MIL-100(Fe) per hour and square meter varies with the different high and low $\mathrm{RH}$ levels. The variation of the moisture adsorption in different conditions can be further implemented in the simulation of energy saving potential in buildings. 


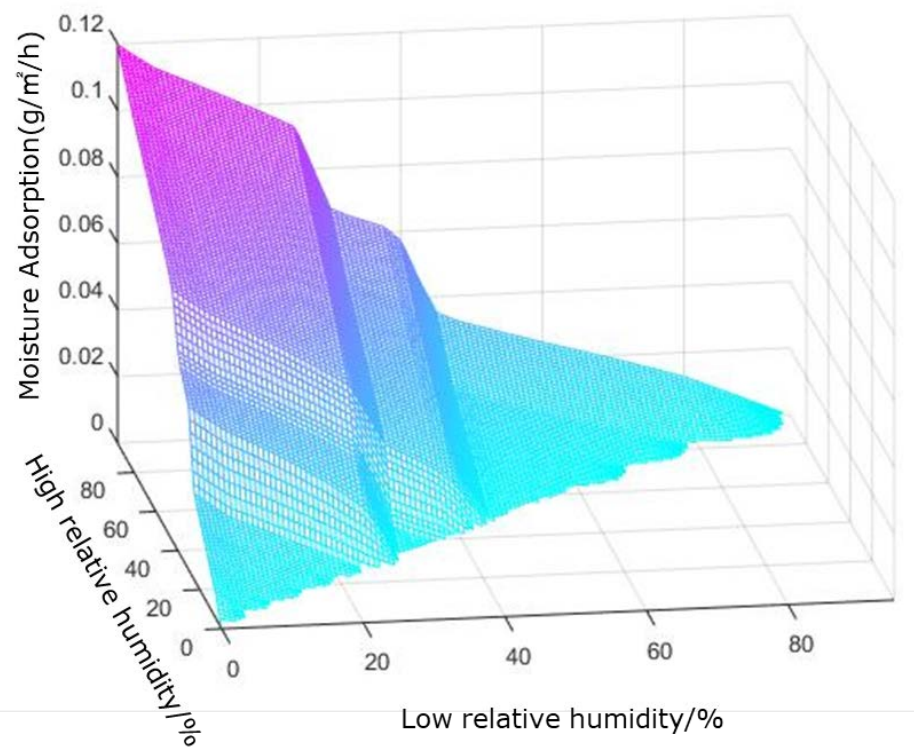

Figure 9. Moisture adsorption with the different high and low relative humidity

\section{Energy saving potential}

The MBV measurement shows MIL-100(Fe) has an excellent performance of moisture buffering, which makes it very promising for indoor passive moisture control. The energy saving potential of applying MIL-100(Fe) in buildings will be discussed in this section.

Since only the hydro environment is considered, humidity ratio has been used instead of relative humidity in this section. The relation between humidity ratio and relative humidity is as follows.

Where $\omega$ is the humidity ratio, $\mathrm{kg} / \mathrm{kg}_{\text {air; }}$ p $p_{a t}$ is the atmospheric pressure, Pa.

4.1 Lumped energy model

272 Since the moisture buffer materials only affect the indoor humidity variation, the model in this 273 paper mainly focuses on the moisture transfer in buildings. The indoor humidity conditions are mainly affected by (1) internal sources and sinks, (2) moisture diffusion through building 
299

envelopes, (3) infiltration, (4) mechanical ventilation, and (5) air conditioning. In the lumped model, the internal sources and sinks are considered (e.g. human activities, moisture adsorption or desorption of moisture buffer materials). Infiltration and mechanical ventilation are expressed together as ventilation rate. Moisture diffusion through building envelopes are neglected in this case since well-insulated modern buildings are normally equipped with vapor barrier, and are almost impenetrable in terms of moisture. There is no air conditioning in the model. The indoor air is assumed to be well mixed, so the humidity at the ventilation exit is the same as the indoor humidity. The humidity of fresh air varies with time. The variation rate of the indoor humidity ratio should follow the equation below:

$m_{\mathrm{r}} \frac{d \omega_{\mathrm{r}}}{d t}=m_{\mathrm{a}}\left(\omega_{\mathrm{fr}}(t)-\omega_{\mathrm{r}}\right)+M_{\mathrm{g}} V_{\mathrm{r}}+M_{\mathrm{MOF}} V_{\mathrm{r}}$

Where, $m_{\mathrm{r}}$ is the mass of indoor air, kg; $m_{\mathrm{a}}$ is mass of ventilation air, $\mathrm{kg}$; $V_{\mathrm{r}}$ is the room volume, $\mathrm{m}^{3} ; t$ is the time, $\mathrm{s} ; M_{\mathrm{g}}$ is the vapor generation rate, $\mathrm{kg} \cdot \mathrm{m}^{-3} \cdot \mathrm{h}^{-1} ; M_{\mathrm{MOF}}$ is the absorption or desorption rate by moisture buffer material multiplies the surface area of material and divides by the room volume, $\mathrm{kg} \cdot \mathrm{m}^{-3} \cdot \mathrm{h}^{-1} ; \omega_{\mathrm{fr}}$ is the humidity of fresh air, $\mathrm{kg} \cdot \mathrm{kg}_{\mathrm{air}}{ }^{-1} ; \omega_{\mathrm{r}}$ is the humidity of indoor air, $\mathrm{kg} \cdot \mathrm{kgair}^{-1}$;

Therefore, in the simplified case, the indoor humidity ratio can be expressed in equation $(8) . \omega_{\mathrm{r}}(0)$ is the initial humidity indoor.

$\omega_{\mathrm{r}}=e^{-\frac{m_{\mathrm{a}}}{m_{\mathrm{r}}} t}\left(\frac{m_{\mathrm{a}}}{m_{\mathrm{r}}} \int \omega_{\mathrm{fr}}(t) e^{\frac{m_{\mathrm{a}}}{m_{\mathrm{r}}} t} d t+\omega_{\mathrm{r}}(0)-\frac{\left(M_{\mathrm{g}}+M_{\mathrm{MOF}}\right) V_{\mathrm{r}}}{m_{\mathrm{a}}}\right)+\frac{\left(M_{\mathrm{g}}+M_{\mathrm{MOF}}\right) V_{\mathrm{r}}}{m_{\mathrm{a}}}$

The time-dependent indoor air humidity can be calculated with the equation above. The influence with and without the moisture buffer phenomenon of MIL-100(Fe) will be both reckoned. Then the latent load removed by MIL-100(Fe) can be derived by comparing the moisture fluctuation with and without MIL-100(Fe).

$Q_{1}=r_{0} m_{\mathrm{r}} \int_{t_{1}}^{t_{2}}\left(\omega_{\mathrm{rno}}-\omega_{\mathrm{rMOF}}\right) d t$ 
300

301

302

303

304

305

306

307

308

309

310

311

312

313

314

315

316

317

318

Where, $Q_{1}$ is the latent load removed by MIL-100(Fe), $\mathrm{kW} ; r_{0}$ is the latent heat of vaporization, $\mathrm{kJ} \cdot \mathrm{kg}^{-1} ; t_{1}$ and $t_{2}$ are the time when human activities began and end, respectively, $\mathrm{s} ; \omega_{\text {rno }}$ is the air humidity ratio without MIL-100(Fe), $\mathrm{kg} \cdot \mathrm{kgair}^{-1} ; \omega_{\text {rMOF }}$ is the air humidity with MIL-100(Fe), $\mathrm{kg} \cdot \mathrm{kgair}^{-1}$.

\subsection{Building model}

The BESTEST base case building (shown in Fig. 10) from the IEA ECBCS Annex 21 [38] was selected as the test building in this study, where it serves as a typical office room. The room is occupied during the daytime from 9:00 am to 17:00 pm and unoccupied the rest of the day. The dimension of the building is $8 \mathrm{~m} \times 6 \mathrm{~m} \times 2.7 \mathrm{~m}$. Internal moisture source, sink, and ventilation cause the indoor humidity variation. The ventilation rate of the room is $0.5 \mathrm{ACH}$ for 24 hours. The internal moisture gain during the occupied period is assumed as $5 \mathrm{~g} \cdot \mathrm{m}^{-3} \cdot \mathrm{h}^{-1}$, which is mainly from the human activities. There is no internal moisture gain during the unoccupied period.

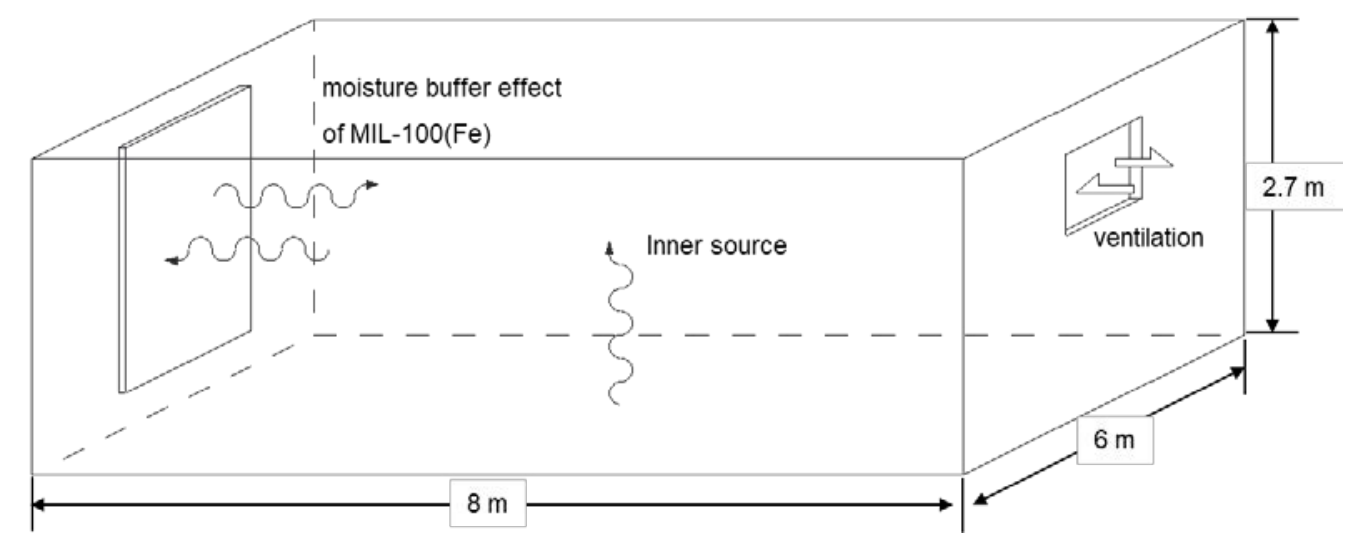

Figure 10. A single office room model

In the case with moisture buffer materials, a $5 \mathrm{~m}^{2}$ wall panel with the thickness of $1.5 \mathrm{~cm}$ made by $7.5 \mathrm{~kg}$ MIL-100(Fe) was installed on the internal surface. The MOF material will absorb and release moisture when there is humidity difference between the day and night. The moisture 
buffering effect is given by Fig. 9. In the case without moisture buffer materials, it is assumed that there is no moisture adsorption and desorption phenomenon at the internal wall surface.

\subsection{Climate}

The geographical locations (weather) of the building have a significant effect on indoor moisture fluctuations and moisture buffer phenomenon. To investigate the effect of MOF on indoor hygrothermal environment and building energy consumption under different climates, four cities in the United States are selected. They are San Francisco (moderate Mediterranean climate), Phoenix (hot desert climate), Salt Lake City (semi-arid climate) and Norfolk (humid subtropical).

The temporal climatic data is derived from the Typical Meteorological Year version 3 data sets [39]. For each city, the dry bulb temperature and relative humidity in one typical summer month have been used to calculate the humidity of fresh air in ventilation.

\subsection{Results and discussion}

The indoor moisture variations with and without the MOF materials for different locations have been calculated and presented in this section. Since the outside relative humidity plays an important role of the regeneration of MOFs, the following discussion will be divided into two parts according to the climatic conditions.

\subsubsection{Dry and moderate climates}

The monthly average outdoor air humidity ratio is $6 \mathrm{~g} \cdot \mathrm{kg}^{-1}$ in Phoenix, $7 \mathrm{~g} \cdot \mathrm{kg}^{-1}$ in Salt Lake City, and $8 \mathrm{~g} \cdot \mathrm{kg}^{-1}$ in San Francisco. The outdoor air with low humidity during the night of these locations could be directly used to regenerate the MOF materials that have adsorbed water vapor during the daytime. The simulated results of the indoor humidity variations with and without 
moisture buffer materials (MIL-100(Fe)) for dry and moderate climates are shown in Fig. 11 13 and Table 3.

Fig. 11 shows the variation of indoor humidity in a typical summer month in Phoenix. In the case without MOF materials, the indoor humidity often exceeds the upper limit of the thermal comfort zone (i.e. RH 60\%). The indoor air should be dehumidified by air conditioning, which causes extra energy use. However, in the case with MOF materials, the indoor hygrothermal environment is well within the comfort zone during most time of the occupied period. The moisture buffer material successfully moderates the fluctuation of indoor humidity.

The daily and monthly indoor moisture fluctuations in Salt Lake City and San Francisco are shown in Fig. 12 and 13. The humidity of the fresh air determines the low level of indoor humidity, and the moisture buffer capacity will be hindered when the low level of indoor humidity is higher than the start of steep adsorption of the water sorption isotherm of MIL100(Fe). Therefore, building located in Phoenix has the most prominent moisture buffer phenomenon because of the dry climate. The moisture buffer phenomenon is weaker in San Francisco due to its higher outdoor humidity.

Table 3 shows the amount of the latent heat removed by MOF in different conditions. In the daytime when the building is occupied, the moisture buffer material MIL-100(Fe) functions as a desiccant and removes a large portion of the latent load without extra energy use. The amount of adsorbed moisture can be calculated since the moisture variations with and without moisture buffer material have been shown in simulation results, then the removed latent load can be further calculated. The results are presented in table 3 . The calculated indoor latent loads are $6.5 \mathrm{~W} \cdot \mathrm{m}^{-2}$, 8.6 W $\cdot \mathrm{m}^{-2}, 12.1 \mathrm{~W} \cdot \mathrm{m}^{-2}$ in Phoenix, Salt Lake City, and San Francisco respectively. The latent loads removed by MIL-100(Fe) are $5.0 \mathrm{~W} \cdot \mathrm{m}^{-2}, 4.1 \mathrm{~W} \cdot \mathrm{m}^{-2}, 2.4 \mathrm{~W} \cdot \mathrm{m}^{-2}$ in the three cities. 
371 Therefore, the latent load saving rates are 76.9\%, 47.7\% and 19.8\% for hot dry climate (Phoenix),

372

373

374

375

376

377

378

379

380

381

382

383 semi-arid climate (Salt Lake City), and moderate Mediterranean climate (San Francisco)

respectively. The air change rate of night ventilation in the above simulation is $0.5 \mathrm{ACH}$.

In order to remove more latent load, the night ventilation should be enhanced. The higher night ventilation rate will remove more indoor moisture released by MIL-100(Fe), and contributes to the lower indoor humidity ratio and higher regeneration rate of MIL-100(Fe). The MBV will increase, and more latent load will be removed by the dryer MIL-100(Fe) during the daytime. According to the simulation results, when the night ventilation rate is raised to 2 ACH from 6 pm to $8 \mathrm{am}$, (the ventilation rate during the day remains as $0.5 \mathrm{ACH}$ ), the latent loads will be totally removed by MIL-100(Fe) in Phoenix and Salt Lake City without extra energy use. The percentage of latent load removed by MIL-100(Fe) is 66.1\% in San Francisco. Night ventilation is a very effective way to regenerate the MOF materials in dry and moderate climates.

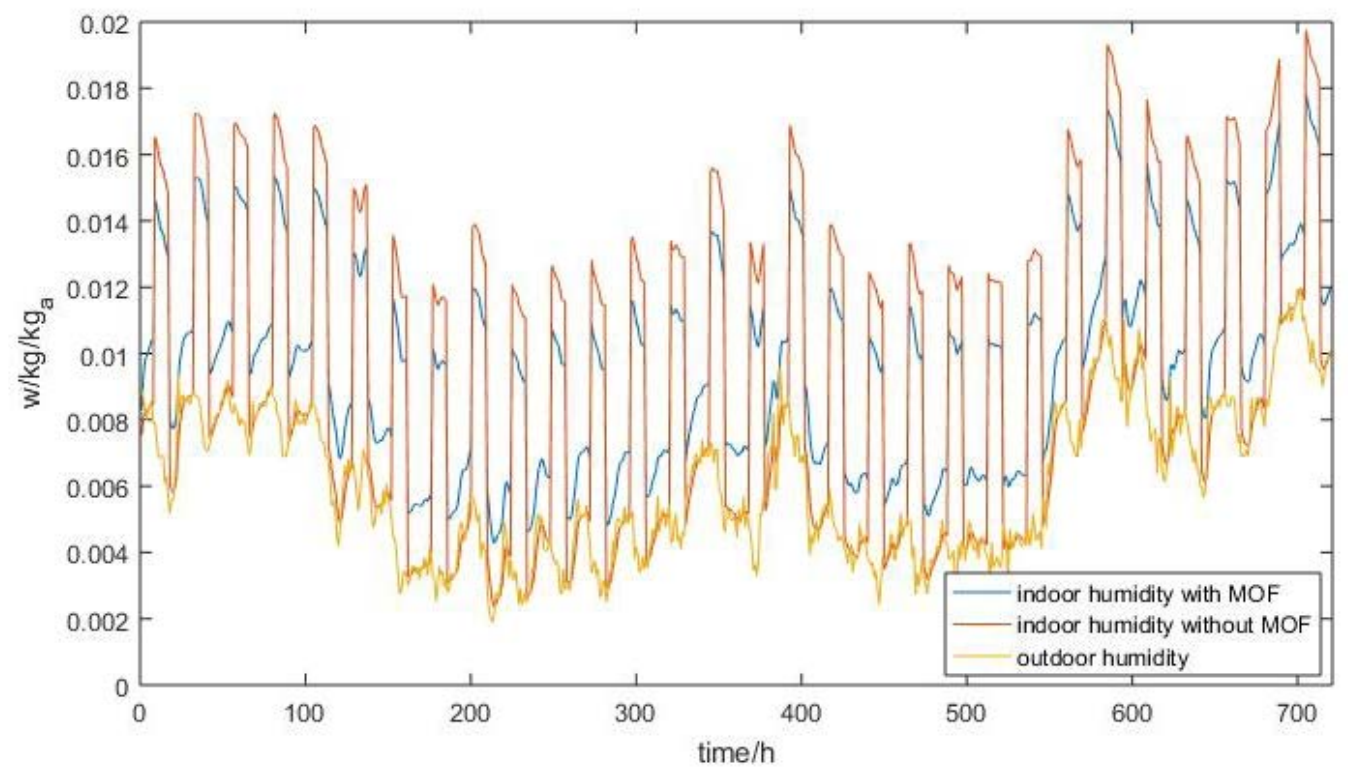

Figure 11. Indoor humidity variation with and without MIL-100(Fe) in Phoenix 


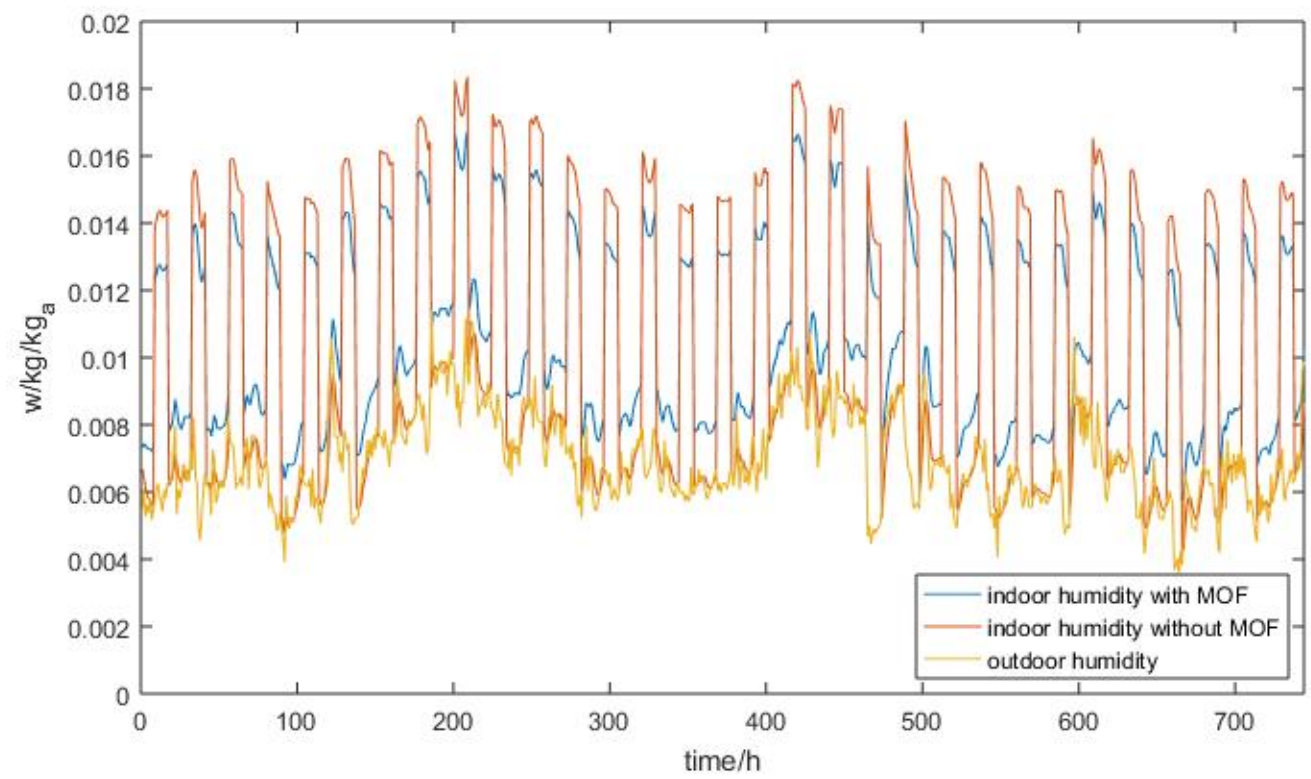

Figure 12. Indoor humidity variation with and without MIL-100(Fe) in Salt Lake City

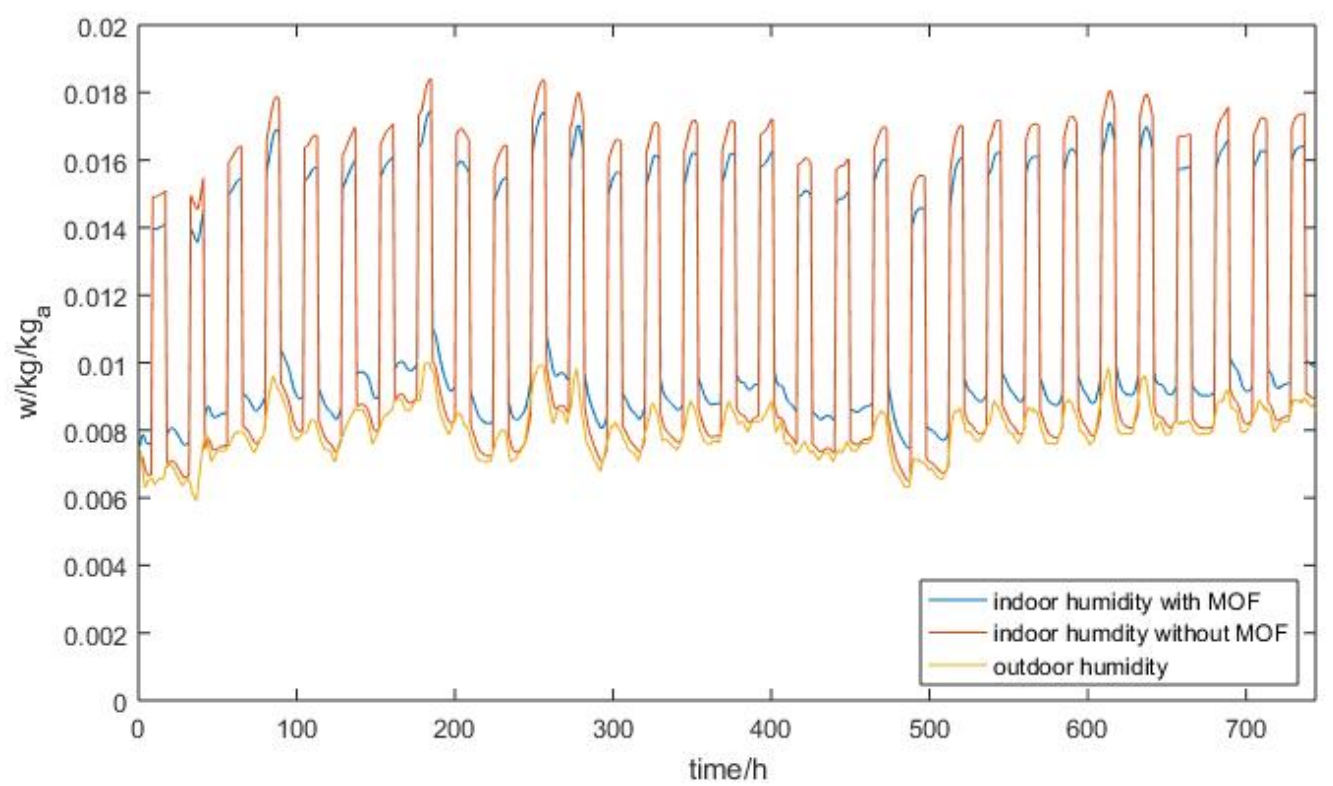

Figure 13. Indoor humidity variation with and without MIL-100(Fe) in San Francisco

4.4.2 Humid climates

In Norfolk, the monthly average outdoor air humidity ratio is $15 \mathrm{~g} \cdot \mathrm{kg}^{-1}$. Figure 14 shows the indoor moisture variations with and without the MOF in Norfolk. In Table 3, the simulation results show that the indoor latent load is $22.2 \mathrm{~W} \cdot \mathrm{m}^{-2}$ in Norfolk. The latent load removed by 
400

401

402

403

404

405

406

407

408

409

MIL-100(Fe) is $0.5 \mathrm{~W} \cdot \mathrm{m}^{-2}$, which is only $2.3 \%$ of the total latent load. Therefore, the energy saving potential is limited, due to the high outdoor humidity throughout the day. Night ventilation cannot effectively reduce the indoor humidity and regenerate the MIL-100(Fe) since the outdoor humidity is still quite high in the evening.

In order to use MIL-100(Fe) for continuous passive control of indoor moisture in the humid climate, it needs to be regenerated with some low-grade energy, such as solar energy or waste heat from thermal power plants etc. Since the regeneration temperature of MIL-100(Fe) is quite low (around $50{ }^{0} \mathrm{C}$ ), it is not difficult to find such a heat source. The simulation results show that $16.3 \mathrm{~W} \cdot \mathrm{m}^{-2}$ can be removed by the regenerated dry MIL-100(Fe), which is $73.4 \%$ of the latent load. The efficiency of the whole system is still very high as there is no need for refrigeration dehumidification. Therefore, MIL-100(Fe) is also applicable for the passive control of indoor moisture in humid climates with proper regeneration strategies. Due to the limitation of the paper length, a detailed description of the regeneration system for MIL-100(Fe) is not within the scope of this paper. We will report the system in the future studies.

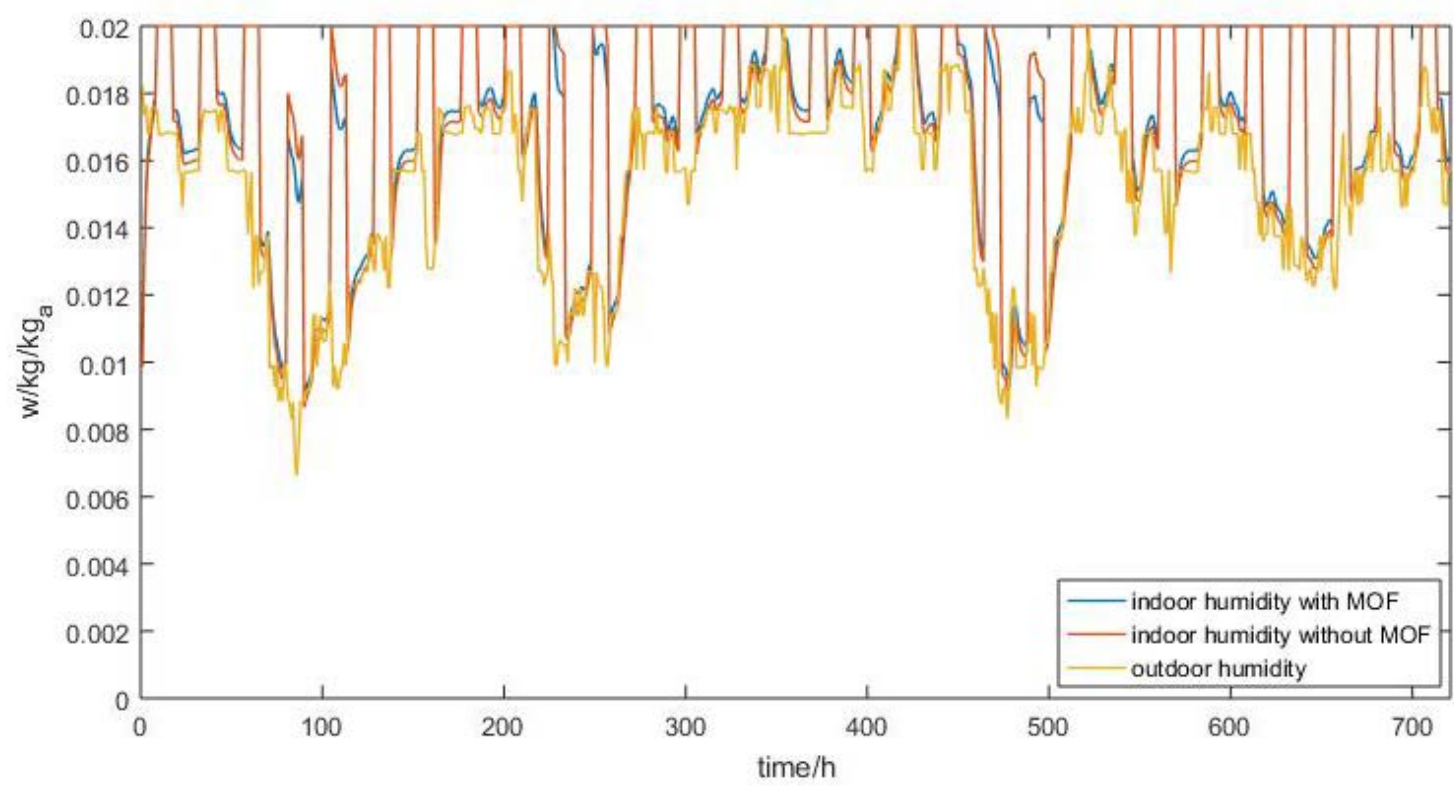
Figure 14. Indoor humidity variation with and without MIL-100(Fe) in Norfolk 
Table 3. Latent load removed by MIL-100(Fe) in different cases

\begin{tabular}{|c|c|c|c|c|}
\hline $\begin{array}{l}\text { Climate } \\
\text { (City) }\end{array}$ & Load and efficiency & $\begin{array}{c}\text { Ventilation rate } \\
\text { is } 0.5 \mathrm{ACH} \text { for } \\
24 \text { hours }\end{array}$ & $\begin{array}{l}\text { MOF regenerated by } \\
\text { enhanced night } \\
\text { ventilation }(2 \mathrm{ACH})\end{array}$ & $\begin{array}{l}\text { MOF regenerated } \\
\text { by low-grade } \\
\text { energy }\end{array}$ \\
\hline \multirow{2}{*}{$\begin{array}{l}\text { Hot dry } \\
\text { (Phoenix) }\end{array}$} & $\begin{array}{l}\text { Latent load removed } \\
\text { by MOF }\left(\mathrm{W} \cdot \mathrm{m}^{-2}\right)\end{array}$ & 5.0 & 6.5 & -- \\
\hline & $\begin{array}{l}\text { Energy saving } \\
\text { (latent load) (\%) }\end{array}$ & 76.9 & 100 & -- \\
\hline \multirow{2}{*}{$\begin{array}{l}\text { Semi-arid } \\
\text { (Salt Lake } \\
\text { City) }\end{array}$} & $\begin{array}{l}\text { Latent load removed } \\
\text { by MOF }\left(\mathrm{W} \cdot \mathrm{m}^{-2}\right)\end{array}$ & 4.1 & 8.6 & -- \\
\hline & $\begin{array}{l}\text { Energy saving } \\
\text { (latent load) (\%) }\end{array}$ & 47.7 & 100 & -- \\
\hline \multirow{2}{*}{$\begin{array}{l}\text { Moderate } \\
\quad \text { (San } \\
\text { Francisco) }\end{array}$} & $\begin{array}{l}\text { Latent load removed } \\
\text { by MOF }\left(\mathrm{W} \cdot \mathrm{m}^{-2}\right)\end{array}$ & 2.4 & 8.0 & -- \\
\hline & $\begin{array}{l}\text { Energy saving } \\
\text { (latent load) (\%) }\end{array}$ & 19.8 & 66.1 & -- \\
\hline \multirow{2}{*}{$\begin{array}{l}\text { Humid } \\
\text { (Norfolk) }\end{array}$} & $\begin{array}{l}\text { Latent load removed } \\
\text { by MOF }\left(\mathrm{W} \cdot \mathrm{m}^{-2}\right)\end{array}$ & 0.5 & -- & 16.3 \\
\hline & $\begin{array}{l}\text { Energy saving } \\
\text { (latent load) (\%) }\end{array}$ & $2.3 \%$ & -- & 73.4 \\
\hline
\end{tabular}

414

415 Overall, in dry and moderate climates, most of the indoor latent loads can be removed by MIL-

$416100(\mathrm{Fe})$ with a night ventilation at $2 \mathrm{ACH}$, which will significantly save the energy for

417 dehumidification of the air-conditioning system. In the cases without the MOF buffer material, all

418 latent loads have to be removed by the air conditioning system via refrigeration dehumidification,

419 which causes a lot of energy use. In the humid climate, the MIL-100(Fe) could remove 73.4\% of

420 the total latent load with the help of a proper regeneration system powered by low-grade energy.

421 Since the regeneration temperature of MIL-100(Fe) is around $50{ }^{\circ} \mathrm{C}$, it is easy to regenerate it by

422 solar energy or other waste heat from different processes. Therefore, MOF buffer materials have

423 a large energy saving potential in buildings under different climate conditions.

\section{Conclusion}

MOF is a new class of crystalline materials with porous structures. Due to its high surface area,

427 porosity, pore volume and low framework density, MOFs have a high capability to adsorb water vapor. MIL-100(Fe) is one type of metal-organic frameworks with large water vapor uptake can be produced on a large scale. 
432 The paper proposed an innovated application of metal-organic framework MIL-100(Fe) as a passive moisture buffer material in buildings. The MIL-100(Fe) has a strong ability to adsorb or release water vapor, and thus can moderate the daily indoor humidity fluctuation. The water sorption isotherms of MIL-100(Fe) have been measured. The steep adsorption occurs between $\mathrm{RH}=25 \%$ and $50 \%$, which is inside of indoor thermal comfort zone. The practical MBV of MOF MIL-100(Fe) has been measured and proved to be one order of magnitude larger than typical building materials, leading to an exceptional moisture buffer ability.

The energy saving potential of applying MIL-100(Fe) to control the indoor humidity has been calculated. In the study, a $5 \mathrm{~m}^{2}$ wall plate filled with MIL-100(Fe) was used to control the latent load of an office room with a size of $48 \mathrm{~m}^{2}$. The simulation results show that most of the latent loads can be removed by MIL-100(Fe) with a night ventilation at $2 \mathrm{ACH}$ in dry and moderate climates. In the humid climate, the MIL-100(Fe) could remove $73.4 \%$ of the total latent load with the help of a proper regeneration system powered by low-grade energy.

In summary, MIL-100(Fe) is a very promising moisture buffer material for the passive control of indoor humidity in different climates. The MOF buffer materials could be easily integrated with mechanical cooling systems to realize the temperature and humidity independent control. Since the MOF materials could handle most of the indoor latent load passively, the refrigeration dehumidification process can be avoided. Dealing only with the sensible load, the evaporation temperature of the cooling system can be raised to above the dew point so the coefficient of performance (COP) and energy efficiency of the system can be dramatically improved. will be the focus of future studies. 
The present research was financially supported by DTU Byg. The authors thank Prof. Christian

Serre and Dr Farid Nouar from the École Normale Supérieure in Paris, France for the preparation of MIL-100(Fe) samples. The authors acknowledge Dr. Kurt Kielsgaard Hansen for all the support in the MBV test.

462

References

464

[1] P. Huovila, Buildings and climate change, United Nations Environment Programme,

Sustainable Consumption and Production Branch, Paris, France, 2009.

466

[2] L. Pérez-Lombard, J. Ortiz, C. Pout, A review on buildings energy consumption information, Energy and Buildings. 40 (2008) 394-398.

[3] M. Karimpour, M. Belusko, K. Xing, F. Bruno, Minimising the life cycle energy of buildings:

Review and analysis, Building and Environment. 73 (2014) 106-114.

470

[4] P. Mazzei, F. Minichiello, D. Palma, HVAC dehumidification systems for thermal comfort: a critical review, Applied Thermal Engineering. 25 (2005) 677-707. review of technologies and strategies, Applied Energy. 104 (2013) 87-104. building energy consumption , Applied Thermal Engineering, 124 (2017) 337-345. Buffer Value of Building Materials, Journal Of ASTM International. 4 (2007) 1-12. capacity, Energy and Buildings. 88 (2015) 91-99. assemblies incorporating formulated hemp-lime, Building and Environment. 93 (2015) 199-209. 
483 [10] M. Rahim, O. Douzane, A. Tran Le, G. Promis, T. Langlet, Characterization and comparison

484 of hygric properties of rape straw concrete and hemp concrete, Construction and Building Materials. 102 (2016) 679-687.

486

[11] M. Abadie, K. Mendonça, Moisture performance of building materials: From material characterization to building simulation using the Moisture Buffer Value concept, Building and Environment. 44 (2009) 388-401.

[12] S. Hameury, Moisture buffering capacity of heavy timber structures directly exposed to an indoor climate: a numerical study, Building and Environment. 40 (2005) 1400-1412.

[13] O. Osanyintola, C. Simonson, Moisture buffering capacity of hygroscopic building materials: Experimental facilities and energy impact, Energy and Buildings. 38 (2006) 1270-

493 1282.

494

[14] Z. Chen, D. Su, M. Qin, G. Fang, Preparation and characteristics of composite phase change 495 material (CPCM) with SiO2 and diatomite as endothermal-hydroscopic material, Energy and 496 Buildings. 86 (2015) 1-6.

497

[15] Z. Wu, M. Qin, M. Zhang, Phase change humidity control material and its impact on building energy consumption, Energy and Buildings, 174 (2018) 254-261.

499

[16] Z. Chen, M. Qin, J. Yang, Synthesis and characteristics of hygroscopic phase change 500 material: Composite microencapsulated phase change material (MPCM) and diatomite, Energy and Buildings. 106 (2015) 175-182.

502

[17] E. Ng, S. Mintova, Nanoporous materials with enhanced hydrophilicity and high water sorption capacity, Microporous and Mesoporous Materials. 114 (2008) 1-26.

504

[18] J. Bauer, R. Herrmann, W. Mittelbach, W. Schwieger, Zeolite/aluminum composite 33 (2009) 1233-1249. 
[19] D. Wragg, R. Johnsen, P. Norby, H. Fjellvåg, The adsorption of methanol and water on

508

509

510

511

512

513

514

515

516

517

518

519

520

521

522

523

524

525

526

527

528

529

530

531

SAPO-34: in situ and ex situ X-ray diffraction studies, Microporous and Mesoporous Materials. 134 (2010) 210-215.

[20] R. AbdulHalim, P. Bhatt, Y. Belmabkhout, A. Shkurenko, K. Adil, L. Barbour et al., A FineTuned Metal-Organic Framework for Autonomous Indoor Moisture Control, Journal Of The American Chemical Society. 139 (2017) 10715-10722.

[21] A. Dhakshinamoorthy, M. Alvaro, H. Garcia, Commercial metal-organic frameworks as heterogeneous catalysts, Chemical Communications. 48 (2012) 11275.

[22] D. Peralta, G. Chaplais, A. Simon-Masseron, K. Barthelet, G. Pirngruber, Synthesis and adsorption properties of ZIF-76 isomorphs, Microporous And Mesoporous Materials. 153 (2012) $1-7$.

[23] M. Bahri, F. Haghighat, H. Kazemian, S. Rohani, A comparative study on metal organic frameworks for indoor environment application: Adsorption evaluation, Chemical Engineering Journal. 313 (2017) 711-723.

[24] H. Li, M. Eddaoudi, M. Keeffe, O. Yaghi, design and synthesis of an exceptionally stable and highly porous metal-organic framework, Letters To Nature. 402 (1999) 276-279.

[25] S. James, Metal-Organic Frameworks, Cheminform. 34 (2003).

[26] P. Horcajada, S. Surblé, C. Serre, D. Hong, Y. Seo, J. Chang et al., Synthesis and catalytic properties of MIL-100(Fe), an iron(iii) carboxylate with large pores, Chem. Commun. (2007) 2820-2822.

[27] G. Férey, Hybrid porous solids: past, present, future, Chem. Soc. Rev. 37 (2008) 191-214. [28] F. Jeremias, A. Khutia, S. Henninger, C. Janiak, MIL-100(Al, Fe) as water adsorbents for heat transformation purposes_a promising application, J. Mater. Chem. 22 (2012) 10148-10151. [29] C. Volkringer, D. Popov, T. Loiseau, G. Férey, M. Burghammer, C. Riekel et al., Synthesis, Single-Crystal X-ray Microdiffraction, and NMR Characterizations of the Giant Pore Metal- 

5697.

534 [30] J. Canivet, A. Fateeva, Y. Guo, B. Coasne, D. Farrusseng, Water adsorption in MOFs: 535 fundamentals and applications, Chem. Soc. Rev. 43 (2014) 5594-5617.

536 [31] N. Burtch, H. Jasuja, K. Walton, Water Stability and Adsorption in Metal-Organic 537 Frameworks, Chemical Reviews. 114 (2014) 10575-10612.

Dehumidification over Hierachically Porous Metal-Organic Frameworks as Advanced Water

Adsorbents, Advanced Materials. 24 (2011) 806-810.

[33] P. Küsgens, M. Rose, I. Senkovska, H. Fröde, A. Henschel, S. Siegle et al., Characterization (2009) 325-330.

[34] S. Narayanan, X. Li, S. Yang, I. McKay, H. Kim, E. Wang, Design and Optimization of

High Performance Adsorption-Based Thermal Battery, (2018).

[35] K. Ng, H. Chua, C. Chung, C. Loke, T. Kashiwagi, A. Akisawa et al., Experimental Engineering. 21 (2001) 1631-1642. D.C., 2008. 


\section{Nomenclature}

\begin{tabular}{|c|c|c|}
\hline \multicolumn{3}{|c|}{ Latin letters } \\
\hline$b_{\mathrm{m}}$ & moisture effusivity & $\mathrm{kg} \cdot \mathrm{m}^{-2} \cdot \mathrm{Pa}^{-1} \cdot \mathrm{s}^{-1 / 2}$ \\
\hline$G$ & moisture transfer in a cycle period & $\mathrm{g} \cdot \mathrm{m}^{-2}$ \\
\hline$m_{\mathrm{a}}$ & mass of ventilation air & $\mathrm{kg}$ \\
\hline$m_{\mathrm{r}}$ & mass of indoor air & $\mathrm{kg}$ \\
\hline$M B V$ & moisture buffer value & $\mathrm{g} \cdot \mathrm{m}^{-2} \cdot \mathrm{RH}^{-1}$ \\
\hline$M_{\mathrm{g}}$ & vapor generation rate & $\mathrm{kg} \cdot \mathrm{m}^{-3} \cdot \mathrm{h}^{-1}$ \\
\hline$M_{\mathrm{MOF}}$ & absorption rate & $\mathrm{kg} \cdot \mathrm{m}^{-3} \cdot \mathrm{h}^{-1}$ \\
\hline$p_{\text {at }}$ & atmospheric pressure & $\mathrm{Pa}$ \\
\hline$p_{\mathrm{s}}$ & saturated vapor pressure & $\mathrm{P}_{\mathrm{a}}$ \\
\hline$Q_{1}$ & latent load & $\mathrm{kW}$ \\
\hline$r_{0}$ & latent heat of vaporization & $\mathrm{kJ} \cdot \mathrm{kg}^{-1}$ \\
\hline$t$ & time & $\mathrm{s}$ \\
\hline$t_{1}$ & the time when human activities began & S \\
\hline$t_{2}$ & the time when human activities end & s \\
\hline$t_{\mathrm{p}}$ & time period & $\mathrm{s}$ \\
\hline$u$ & moisture content & $\mathrm{kg} \cdot \mathrm{kg}^{-1}$ \\
\hline$V_{\mathrm{r}}$ & room volume & $\mathrm{m}^{3}$ \\
\hline \multicolumn{3}{|c|}{ Greek letters } \\
\hline$\delta_{\mathrm{p}}$ & water vapor permeability & $\mathrm{kg} \cdot \mathrm{m}^{-1} \cdot \mathrm{s}^{-1} \cdot \mathrm{Pa}^{-1}$ \\
\hline$\rho_{0}$ & dry density of the material & $\mathrm{kg} \cdot \mathrm{m}^{-3}$ \\
\hline$\varphi$ & relative humidity & $\%$ \\
\hline$\omega$ & humidity ratio & $\mathrm{kg} / \mathrm{kg}_{\text {air }}$ \\
\hline$\omega_{\mathrm{fr}}$ & humidity of fresh air & $\mathrm{kg} \cdot \mathrm{kg}_{\mathrm{air}}{ }^{-1}$ \\
\hline$\omega_{\mathrm{r}}$ & humidity of indoor air & $\mathrm{kg} \cdot \mathrm{kg}_{\mathrm{air}}{ }^{-1}$ \\
\hline$\omega_{\text {rno }}$ & air humidity ratio without MIL-100(Fe) & $\mathrm{kg} \cdot \mathrm{kg}_{\mathrm{air}}{ }^{-1}$ \\
\hline$\omega_{\mathrm{rMOF}}$ & air humidity with MIL-100(Fe) & $\mathrm{kg} \cdot \mathrm{kg}_{\mathrm{air}^{-1}}$ \\
\hline
\end{tabular}

